\title{
Contents Vol. 41 (1-3)
}

Improving Our Professional Writing

Future Crop Use of Forest Land (Toronto Annual Meeting Session Chaired by Prof. A. S. Michell)

Future Utilization of Wood for Pulp and Paper in Canada by M.

Wayman
Future Management for Increased Productivity by A. P. MacBean -

Future Crop Use of Forest Land (Toronto Annual Meeting Session Chaired by $P$. Addison)

Quality Requirements in the Forests of the Future by S. G. Reid and

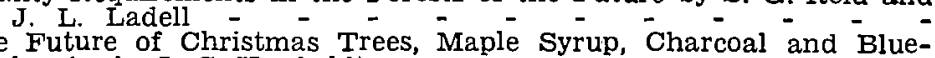
The Future of Christmas Trees, Maple Syrup, Charcoal and BlueFuture Wilduife Management on Forest Lands by Bruce s. Wright -

Recreation and Conservation (Toronto Annual Meeting Session Chaired by J. W. Giles)

Interpretation in Ontario Provincial Parks by A. F. Helmsley - Outdoor Recreation Needs of Metropolitan Areas by $K$. G. Higgs -

Forest Mensuration (Toronto Annual Meeting Session Chaired by T. G. Honer)

"Inside Forest Mensuration by $H$. E. Young T. W Dwight Confounded" the Sad Story of Forest Regulation by T. W. Dwight - - Valuation Method by Judelch, translated by Some Considerations Concerning the Establishment of optimum Plot Size in Forest Survey by G. Tardif

Seedbed, Canopy and Moisture Effects on Growth of Yellow Birch Seedlings by $B$. S. P. Wang -

Stand Improvement with White Spruce Planted with Concurrent Dybar (Fenuron) Herbicide 'Treatment by R. F. Sutton -

Mort en Cime du Bouleau Jaune Causee Par Le Champignon Nectria Galligena by Marcel Lortie - _ _ _ _ _ _ _ News and Notes

Re-organization and Expansion of the Federal Forestry Dept.

Eastern Rockies Conservation Board

Senior Appointees Dept. of Forestry

New Research Laboratory Opened at Victoria - $-\overline{-}-\overline{-}-$ B.C.'s Future in Forest Products Trade in Asia and the Pacific Area National System of Evaluating Land Capability for Forestry Adopted for ARDA Use at Ottawa Meeting

Forest Terminology Project -

University of Toronto Awards

1968 North American Forest Soils Conference

Association of B.C. Registered Foresters -

Committee on Forest Tree Breeding - - of IUFRO in Turkey Rumania and the Eighth Congress of the SSS, 1964 - $-\overline{-}=$

For the Sake of Argument

Did You Like the New Supplement? - - - - - - - 130 Does Animal Damage Deserve Further Study? - - $-=-5$ Can Genetics Solve Everything? - - - - - - - - 132

Sir Winston Was a Forester at Heart - - - - - - -

Eigenvector Analyses Show That Birch and Pine Häe similä Form In Sweden and British Columbia by Joran Fries - _ _ - -135

Reviews and Current Publications - - - - - - - -140

Institute Affairs

Policy Statement - - - - - - - - - - - 142

Come to the Annual Meeting $=-z=-z=-z$

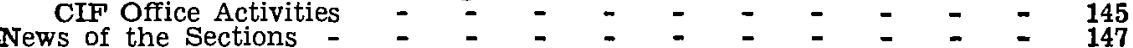

Membership Changes $-\overline{-}-\overline{-}-\overline{-}-\overline{-}-\overline{-} 156$ 
Editorial

The Uncertain Forester

John Walters

Control of an Integrated Company's Wood Supply

K. G.

Height Sampling in Red Pine and White Spruce Plantations

W. M. Stiell

The Effect of Chemical Sterilization on the Fungus Population of Soll in Relation to Root Disease of Douglas Fir Seedlings

W. J. Bloomberg

Eco-Geographic Criteria for Mapping Forest Habitats in Southeastern Manitoba

$$
\text { D. Mueller-Dombois }
$$

A Method of Preparing an Edge-punched Card Literature Reference File

G. S. Chester - - - - - - - -

The Comparison of Tree Qualities

P. L. Northcott -

Observations on Foliage Nutrient Content of Several Coniferous Tree Species in British Columbia

J. D. Beaton, A. Moss, I. MacRae, J. W. Konkin, W. P. T. McGhee, and R. Kosick - -

Wildlife Values in Forestry in Ontario

C. H. D. Clarke

Sulphur Dioxide Injury to Trees in the Vicinity of Petroleum Refineries

S. N. Linzon - - - - $-\quad-\quad-\quad-\quad-\quad-$

161

162

169

175

182

Machine to Prepare Coniferous Foliage Samples for Analysis

J. G. Kemp, W. G. H. Ives, and G. Hergert - - - - -

The Need to Study Silvicultural Effects of Mechanized Logging Systems in Eastern Canada

G. F. Weetman - - - - - - - - - - - 252

News and Notes

Sixth World Forestry Congress - $\quad$ - $-\quad-\quad-\quad-\quad$ - 257

Corrections - - $\quad$ - $\quad$ - $\quad$ - - - $-\quad-257$

An Improved Manual Transplanting Method - - - - - 258 Reviews

Statistical Techniques in Forestry - - - - - - - - 260

Morphogenesis of Douglas fir - - - - - - - - 260

Wildlife Biology - $-\quad-\quad-\quad-\quad-\quad-\quad-\quad-\quad-\quad-263$

Obituaries

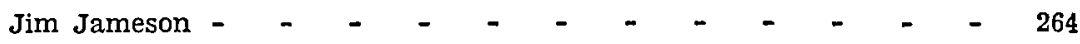

Dr. R. B. Miller - - - - - - - - - - - 265

William A. MacNeill - - - - - - - - - - 265

Institute Affairs

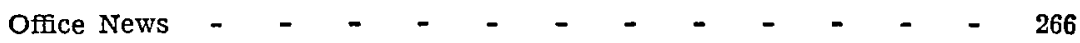

Development of Park Policy - - - - - - - - - 266

News of the Sections - - - - - - - - - - - 272

Membership Changes - - - _ - - - - - - $\quad 281$ 
Editorial Article - - - - $\quad$ - $\quad$ - - - - - - -

Effect of Magnesium and Potassium Fertilization on a 20-year-old Red Pine Plantation

J. D. Gagnon

Maple Dieback in Ontario

H. D. Griffin - - - - - - - - - - - 295

Describing Forest Fires - Old Ways and New

C. E. Van Wagner - - - - - - - - - - 301

Some Effects of Foliage Saprophytes in the Control of Melampsora Leaf Rust on Black Cottonwood John E. Bier - - - - - - - - - - 306

Cone Production and seedfall in a Mature White Spruce Stand R. M. Waldron - - $\quad$ - $\quad$ - $\quad$ - $\quad$ - $\quad$ - $\quad$ - $\quad 314$

Growth Habits of Mountain Maple in the Ontario Clay Belt

A. B. Vincent - - - - - - - - - - - 330

A Geographical Appraisal of the Soviet Forest Resource

Robert M. Bone - - - - - - - - - - 345

Measurement of Wood Moisture Content Using the Colman Electrode

W. J. Bloomberg and D. Farrell - - - - - - - 352

News and Notes

S. A. F. to meet in Detroit - - - - - - - - 364

International meeting of tree breeders in Mexico - - - - 364

Reviews

Forest Inventory - - - - - - - - - - - 365

Russian-English Biological Dictionary - - - _ - - 366

Soviet Progress in Forest Fire Control - $\quad$ - $\quad$ - $\quad$ - $\quad-\quad-366$

Piezoelectric Properties of Wood - - - - - - - 366

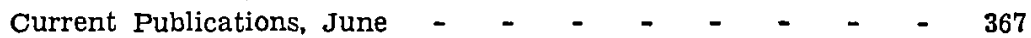

Current Publications, September - $\quad-\quad-\quad-\quad-\quad-369$

For The Sake of Argument

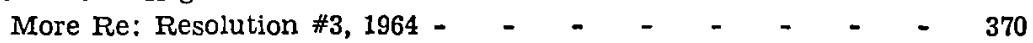

Obituary

William Stanley Hepher - - - - - - - - - 371

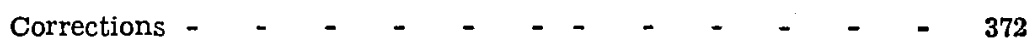

Maritimes News - $-\quad-\quad-\quad-\quad-\quad-\quad-\quad-\quad-\quad 372$

Institute Affairs - - - - - - - - - - - - 373

News of the Sections - - - - - - - - - - -374

Employment - - - - - - - - - - - - - 377

Memberships Changes - - _ - _ - - _ - - - 378

(Continued on page 382) 